Journal of Animal and Veterinary Advances 11 (6): 760-762, 2012

ISSN: $1680-5593$

(C) Medwell Journals, 2012

\title{
Polymorphism of Ovar-DRB1 Second Exon with PCR-RFLP Technique in Arabi Sheep Population of Khuzestan Province
}

\author{
Mojtaba Lotfi, Mohammad Taghi Beigi Nassiri, Hedayatollah Roshanfekr and Jamal Fayazi \\ Department of Animal Science, Faculty of Animal Science, Food Science and Technology, \\ Agricultural and Natural Resources Ramin (Khuzestan) University, Ahvaz, Iran
}

\begin{abstract}
Major Histocompatibility Complex (MHC) plays a pivotal role in antigen presentation for eliciting immune responses against invading pathogens. The best characterized genetic control of disease resistance and immune response in animals are associated with $\mathrm{MHC}$. Therefore, in this study polymorphism of Ovar-DRB1 in DNA samples of 111 heads Arabi sheep using Polymerase Chain Reaction (PCR) and Restriction Fragment Length Polymorphism (RFLP) method was examined. Identities of 18 different patterns and 8 distinct DRB1 alleles among Arabi sheep have been determined. There is not deviation in Ovar-DRB1 gene from Hardy-Weinberg equilibrium in this population, results showed. Obtained results have revealed that the exon 2 region of Ovar-DRB1 was highly polymorphic on Arabi sheep.
\end{abstract}

Key words: Arabi sheep, MHC, Ovar-DRB1, PCR-RFLP, Khuzestan province, Iran

\section{INTRODUCTION}

The Major Histocompatibility Complex (MHC) plays a central role in the immune response of vertebrates. The extreme polymorphism enables the host to recognize enormous numbers in $M H C$ genes of foreign peptides to trigger an immune reaction. The $\mathrm{MHC}$ of sheep is known as Ovar, located on chromosome 20 (Dukkipati et al., 2006).

Ovar-MHC is poorly characterised, compared to other domestic animals. However, its basic structure is similar to that of other mammals, comprising class I-III regions. The class I region is poorly characterised and there is a significant controversy over the number of classical class I loci. Initial studies in this regard relied mainly on the use of alloantisera in micro-lymphcytotoxicity assays. The class II region is better characterized but the class III region is the least. Products of the class I and II genes, MHC molecules, play a pivotal role in antigen presentation required for eliciting immune responses against invading pathogens.

However, when MHCs of different mammals are compared, some regions appear to be well conserved and others vary widely (Kelley et al., 2005). In general, the class II and class III regions are orthologous, i.e., they are clearly derived from a single ancestor without being subjected to major rearrangements (except in ruminants) and their gene order is conserved. Chardon et al. (1985) reported that the serologically detected class I sheep leukocyte antigens are coded by $M H C$ genes. Class II genes are members of the immunoglobulin superfamily of genes which are functionally specialised for presentation of antigenic peptides mainly derived from extracellular proteins and parasites to the $\mathrm{T}$ cells receptors. The Ovar class II genes encode polymorphic glycoprotein composed of non-covalently linked $\alpha$ and $\beta$-subunits that play a basal role in the initiation of the immune response to pathogen-derived peptide antigens. The highly polymorphic genes of the $\mathrm{MHC}$ play a central role in the immune recognition of pathogens and parasites. These genes encode $\mathrm{MHC}$ class I and II molecules that present peptide antigens to $\mathrm{T}$ cells, initiating immune recognition of foreign antigens (Falk et al., 1991).

Andersson and Rask (1988) demonstrated that the most polymorphic among the $M H C$ genes is the DRB locus. Ovar-DRB genes exist in multiple copies, some functional and others non-functional. Konnai et al. (2003) reported that 106 Ovar-DRB1 alleles have been identified by DNA sequencing of exon 2 from various breeds of sheep. Several studies (Thursz et al., 1997; Carrington et al., 1999; Penn et al., 2002; Stear et al., 2005) have confirmed this selective advantage of $\mathrm{MHC}$ heterozygosity against infectious agents.

The Arabi sheep is one of the most important Iranian native breeds. These animals are fat-tailed, medium-sized and well adapted to extreme temperatures and conditions

Corresponding Author: Mojtaba Lotfi, Department of Animal Science, Faculty of Animal Science, Food Science and Technology, Agricultural and Natural Resources Ramin (Khuzestan) University, Ahvaz, Iran 
in Khuzestan province and Southwestern part of Iran (Ezzatpour, 2003). The current study was aimed at analyze the genetic diversity of the Ovar-DRB1 locus in Arabi sheep by PCR-RFLP technique.

\section{MATERIALS AND METHODS}

Animal and DNA extraction: This study was conducted on a total of 110 heads Arabi sheep from four different regions of Khuzestan province as follows: Shadegan region ( $\mathrm{n}=30)$, Hoveyzeh region $(\mathrm{n}=28)$, Dasht-eAzadegan region $(n=27)$ and Mollasani region $(n=26)$. All the animals were unrelated and selected at random. From each animal, about 3-5 cc of blood was collected from the jugular vein with vacuum tubes coated with EDTA and transported in the Central Laboratory of Agricultural and Natural Resources Ramin (Khuzestan) University and stored at $-20^{\circ} \mathrm{C}$ until DNA extraction. Genomic DNA extracted from $100 \mu \mathrm{L}$ of blood according to Boom et al. (1990) method. Quality and quantity of DNA were measured by electrophorese in agarose gel $0.8 \%$.

PCR-RFLP: A region exon 2 of the $O$ var-DRB1 gene was amplified to produce a 296 bp fragment. Primers described for the sequence following. Study of Konnai et al. (2003) were used and they were as follow sequencing: OLA-ERB1 (GC) 5'-CCG GAA TTC CCG TCT CTG CAG CAC ATT TCT T-3' and OLA-XRBI (5'-AGC TCG AGC GCT GCA CAG TGA AAC TC-3').

A total of $25 \mu \mathrm{L}$ reaction mixture containing $100-150 \mathrm{ng}$ DNA template, $15 \mathrm{pm}$ of each primer, $200 \mu \mathrm{L}$ of each dNTP, $1.5 \mathrm{mM} \mathrm{MgCl}_{2}, 1 \mathrm{U}$ Taq DNA polymerase and $2.5 \mathrm{~mm}$ PCR buffer $1 \mathrm{x}$. The optimal follow-up reactions and the patterns of thermal gradient method with 30 cycles under the most ideal conditions for proliferation area were selected. At the first, starting denaturation $\left(95^{\circ} \mathrm{C}\right.$ for $5 \mathrm{~min}$ ), the next step with the temperature $95^{\circ} \mathrm{C}$ for $30 \mathrm{sec}$ and the temperature annealing each cycle, $64-65^{\circ} \mathrm{C}$ for $30 \mathrm{sec}$ and $72^{\circ} \mathrm{C}$ for $1 \mathrm{~min}$ temperature was extension. The temperature of extension was $72^{\circ} \mathrm{C}$ in $10 \mathrm{~min}$ and then it was $4^{\circ} \mathrm{C}$ in $20 \mathrm{~min}$ in the final stage. Samples were resolved on $1.2 \%$ agarose gel electrophoresis.

After amplification of this gene polymorphism to the desired gene fragments by enzymatic digestion with enzymes were introduced in the studies. Enzyme RsaI, a four nucleotide sequence GGCC at the junction of $\mathrm{C}$ and $\mathrm{G}$ are identified and broken. After adding the final mix-up micro tube and centrifuged, the samples for $16 \mathrm{~h}$ at $37^{\circ} \mathrm{C}$ was placed in a warm bath. Then $8 \mathrm{~mL}$ of digestion products by $2.5 \%$ agarose gel electrophoresis was used to determine the size bands $50 \mathrm{bp}$ size markers.
The amplified fragment were digested with RsaI restriction endonuclease and then subjected to electrophoretic separation in ethidium bromide-stained $2.5 \%$ agarose gel. Samples were electrophoresed for $90 \mathrm{~min}$ at $80 \mathrm{~V}$. Then gels were photographed under UV light with a Gel Doc System. Investigation of allelic and genetic frequencies performed by Chi-square and Hardy-Weinberg equilibrium carried out by GenAlex 6.3 (Peakall and Smouse, 2006).

\section{RESULTS AND DISCUSSION}

Ovar-DRB1 polymorphism was analyzed by PCR amplification and RFLP of Ovar-DRB1 exon 2 in Arabi sheep population in Khuzestan province. DNA bands of expected size (296 bp) of the following replication PCR were obtained (Fig. 1).

When each amplified product was cleaved by restriction enzyme, 8 different patterns were observed in RsaI digests (Table 1 and Fig. 2).

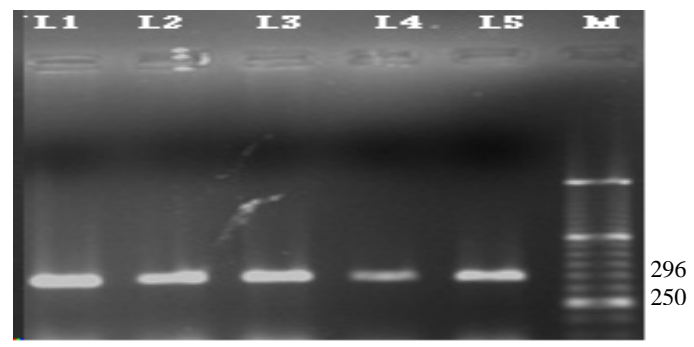

Fig. 1: The 296 bp amplified fragment of Ovar $M H C$ genes

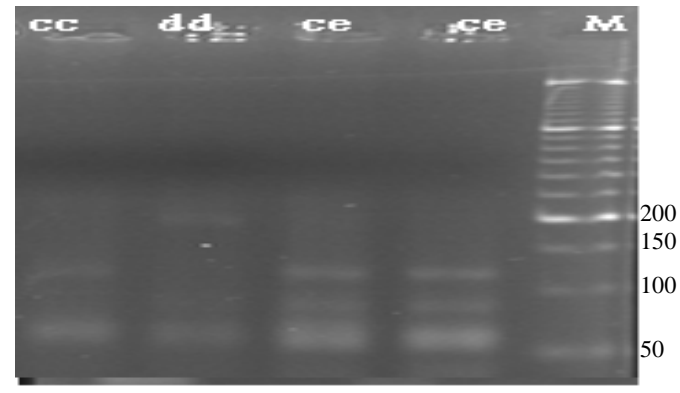

Fig. 2: PCR-RFLP analysis of the second exon of Ovar-DRB1 gene (296 bp) from Arabi Sheep

Table 1: Allelic frequencies of the exon 2 of $M H C-D R B 1$ gene in Arabi sheep

\begin{tabular}{llc}
\multicolumn{2}{c}{ sheep } \\
\hline Alleles & Size of bands in identified alleles (bp) & Allelic frequency \\
\hline $\mathrm{A}$ & 296 & 3.60 \\
$\mathrm{~B}$ & $240 / 56$ & 21.60 \\
$\mathrm{C}$ & $117 / 69 / 56 / 54$ & 24.75 \\
$\mathrm{D}$ & $186 / 56 / 54$ & 9.90 \\
$\mathrm{E}$ & $84 / 69 / 56 / 54 / 33$ & 17.60 \\
$\mathrm{~F}$ & $84 / 56 / 54 / 39 / 33 / 30$ & 1.35 \\
$\mathrm{G}$ & $84 / 56 / 54 / 39 / 30$ & 0.90 \\
$\mathrm{H}$ & $147 / 56 / 54 / 39$ & 20.30 \\
Konnai et al. $(2003)$ &
\end{tabular}


The RsaI restriction showed in study the 8 restriction patterns $\mathrm{a}, \mathrm{b}, \mathrm{c}, \mathrm{d}, \mathrm{e}, \mathrm{f}, \mathrm{g}, \mathrm{h}$. In Arabi sheep 6 homozygous genotypes: bb, cc, dd, ee, gg, hh and 12 hetrozygous genotypes: $a b, a c, b d, b e, b f, b h, c d, c e, c h, d e, d h$, he were observed.

Allele $\mathrm{c}$ and $\mathrm{b}$ had the highest allelic frequency $(24.77$ and $21.6 \%$, respectively) and genotype ce and bh were the most frequent patterns exhibited (18 and 17.1, respectively) in population of Arabi sheep. The number of alleles (na), expected alleles (ne), observed heterozygosity and expected heterozygosity rates were $8,5.223,0.667$ and 0.809 , respectively. Chi-square $\left(\chi^{2}\right)$ test indicated that this population was at Hardy-Weinberg equilibrium and any selection done for these loci in mentioned population.

Evaluation of level hetrozygosity dependent on $M H C$ gene in population is very high. That is explanatory of good genetic diversity because Heterozygosity is one of importance indices in detect of the genetic diversity and always is polestar of animal's breeders.

\section{CONCLUSION}

The findings of the present study confirmed and revealed that the exon 2 region of Ovar-DRB1 was highly polymorphic in Arabi sheep and this population was at Hardy-Weinberg equilibrium too.

\section{REFERENCES}

Andersson, L. and L. Rask, 1988. Characterization of the $\mathrm{MHC}$ class II region in cattle. The number of $D Q$ genes varies between haplotypes. Immunogenetics, 27: $110-120$.

Boom, R., C.J.A. Sol, M.M.M. Salimans, CJ. Jansen, P.M.E.W. van Dillen and J. van der Noordaa, 1990. Rapid and simple method for purification nucleic acid. J. Clin. Microbiol., 28: 495-503.

Carrington, M., G.W. Nelson, M.P Martin, T. Kissner and D. Vlahov et al., 1999. HLA and HIV-1: Heterozygote advantage and $\mathrm{B}^{*} 35-\mathrm{Cw}^{*} 04$ disadvantage. Science, 283: $1748-1752$.
Chardon, P., M. Kirszenbaum, P.R. Cullen, C. Geffrotin and C. Auffray et al., 1985. Analysis of the sheep MHC using HLA class I, II and C4 cDNA probes. Immunogenetics, 22: 349-358.

Dukkipati, V.S.R., H.T. Blair, D.J. Garrick and A. Murray, 2006. Ovar-Mhc-ovine major histocompatibility complex: Structure and gene polymorphisms. Genet. Mol. Res., 5: 581-608.

Ezzatpour, M., 2003. Native Iranian sheep and goat production. Moallef Publication, Tehran, Iran.

Falk, K., O. Rotzschke, S. Stevanovic, G. Jung and H.G. Rammensee, 1991. Allele-specific motifs revealed by sequencing of self-peptides eluted from $\mathrm{MHC}$ molecules. Nature, 23: 290-296.

Kelley, J., L. Walter and J. Trowsdale, 2005. Comparative genomics of major histocompatibility complexes. Immunogenetics, 56: 683-695.

Konnai, S., Y. Nagaoka, S. Takesima, M. Onuma and Y. Aida, 2003. Technical note: DNA typing for ovine MHC DRB1 using polymerase chain reactionrestriction fragment length polymorphism (PCRRFLP). J. Dairy Sci., 86: 3362-3365.

Peakall, R. and P.E. Smouse, 2006. GENALEX 6: Genetic analysis in Excel. Population genetic software for teachingand research. Mol. Ecol. Notes, 6: $288-295$.

Penn, D.J., K. Damjanovich and W.K. Potts, 2002. MHC heterozygosity confers a selective advantage against multiple-strain infections. Proc. Natl. Acad. Sci. USA., 99: 11260-11264.

Stear, M.J., G.T. Innocent and J. Buitkamp, 2005. The evolution and maintenance of polymorphism in the major histocompatibility complex. Vet. Immunol. Immunopathol., 108: 53-57.

Thursz, M.R., H.C. Thomas, B.M. Greenwood and A.V.S. Hill, 1997. Heterozygote advantage for HLA class- $\Pi$ type in hepatitis B virus infection. Nat. Genet., 17: 11-12. 